Article

\title{
Kinetic Studies on Gas-Based Reduction of Vanadium Titano-Magnetite Pellet
}

\author{
Junwei Chen, Weibin Chen, Liang Mi, Yang Jiao and Xidong Wang * \\ Department of Energy and Resources Engineering, College of Engineering, Peking University, \\ Beijing 100871, China; 1401111582@pku.edu.cn (J.C.); chenwb@pku.edu.cn (W.C.); \\ liangmicoming@163.com (L.M.); jiaoyang518@foxmail.com (Y.J.) \\ * Correspondence: xidong@pku.edu.cn; Tel.: +86-10-8252-9083
}

Received: 5 January 2019; Accepted: 14 January 2019; Published: 16 January 2019

\begin{abstract}
Vanadium titano-magnetite (VTM) is a significant resource in China-analysis shows that China possesses approximately 10 billion tons of VTM. In this study, we characterize VTM's isothermal reduction mechanisms in the mixture of $\mathrm{H}_{2}, \mathrm{CO}$, and $\mathrm{N}_{2}$ where the variables considered include reduction time, reduction temperature, gas composition, and pellet size. The kinetics of the reduction process were studied following a shrinking core model. The results indicate that the reduction degree of oxidized VTM pellets increases with increases of reduction time and reduction temperature but decreases with increasing pellet size. Moreover, we found that an increase of $\mathrm{H}_{2} /\left(\mathrm{H}_{2}\right.$ $+\mathrm{CO}$ ) ratio induced an increase of the reduction degree. We discuss the transformation of main Ti-bearing mineral phases, and we consider the most probable reaction mechanism. For the entire reduction process, the kinetic results confirm the existence of an early and later stages that are controlled by interface chemical reaction and diffusion, respectively. Furthermore, the results show that the diffusion-control step can be observably shortened via decreased pellet size because a thinner product layer is formed during the reduction process. Our study thus provides a valuable technical basis for industrial applications of VTM.
\end{abstract}

Keywords: vanadium titano-magnetite; gas-based reduction; carbon monoxide; hydrogen; and nitrogen; kinetics; pellet size

\section{Introduction}

Vanadium titano-magnetite (VTM) is a type of multi-elements-coexistent mineral that contains iron $(\mathrm{Fe})$, titanium $(\mathrm{Ti})$, vanadium $(\mathrm{V})$, and various rare metals [1-3]. VTM is becoming increasingly important because of its significant value in the high-tech industries [4-6]. According to statistics, more than 10 billion tons VTM resources are located in China. The abundant reserves ranks China third in the world following Russia and South Africa [7,8]. The VTM with $\mathrm{TiO}_{2}$ and $\mathrm{V}_{2} \mathrm{O}_{5}$ is abundant in Panxi Area of China, where the amount of $\mathrm{TiO}_{2}$ and $\mathrm{V}_{2} \mathrm{O}_{5}$ present account for more than $90 \%$ and $80 \%$, respectively, of the total quantity of China [9-11]. Hence, it is important to utilize the VTM in the Panxi Area of China as the main supply of Ti and V. Especially, the extraction of valuable elements such as vanadium in VTM has attracted the attention of many scholars [12,13]. In particular, vanadium plays a major role in many fields such as biological and medicine fields [14]. The crystalline structure of VTM is complicated because the Ti and Fe are closely associated with each other in the ore, and V is as isomorphism in the lattice of VTM [15]. The key to utilizing the resource lies in how to separate the Fe, V and Ti efficiently. The processes involved in utilizing VTM fall into two categories: blast furnace $(\mathrm{BF})$ processes and non-BF processes $[16,17]$. The $\mathrm{BF}$ technology is widely recognized because it has been employed for a long time in China and Russia. However, this process does have several drawbacks. First, the continual shortage of coke resource limits development of BF technology. 
In addition, the introduction of limestone as a solvent in blast furnaces decreases the grade of $\mathrm{TiO}_{2}$, and the reaction of $\mathrm{TiO}_{2}$ with limestone to produce perovskite leads to almost no recycling of titanium available in VTM. Currently, much research has been conducted on the comprehensive utilization of VTM by non-BF processes, and several technological processes for the utilization of VTM have already been developed. The pre-reduction electric furnace smelting process is the most promising processes due to the high recovery rate of valuable elements and low cost [15].

Reduction is an essential procedure in the pre-reduction electric furnace smelting process. Hence, it is extremely important to investigate the reduction behavior and kinetics of VTM. In recent decades, a large number of studies have been carried out to investigate reduction behavior and kinetics of VTM. Most previous research on the reduction behavior and kinetics of VTM was mainly focused on the process that used coal as the reducing agent [12,13,18-22]. However, the rate of the reduction reaction is relatively slow in coal-based reduction process. In addition, with political pressure focused on environmental protection, gas-based reduction of VTM is becoming increasingly prevalent. Compared with coal-based reduction, gas-based reduction has a number of advantages, such as higher reduction degree, better processing capacity as well as less pollution [12,13,23-26]. Although a few papers have dealt with the gas-based reduction of VTM, there are two important problems in the previous research on the gas-based reduction behavior and kinetics of VTM. Firstly, many reduction experiments were based on the use of pure hydrogen $\left(\mathrm{H}_{2}\right)$ or pure carbon monoxide $(\mathrm{CO})$. Nevertheless, most of the reaction is between the VTM and a gas mixture of $\mathrm{CO}, \mathrm{H}_{2}$ and $\mathrm{N}_{2}$ in the actual industrial process. Second, the previous studies did not consider the particle size of oxidized VTM pellets; this can play an important role in the reduction kinetics. Therefore, previous experiments were not carried out by simulating the actual reduction gas, and thus they are problematic for guiding the industrial application of VTM.

In this paper, the gas-based reduction kinetics of oxidized VTM pellets was examined systematically. The effects of reduction time, reduction temperature, gas composition of different $\mathrm{H}_{2} /\left(\mathrm{H}_{2}+\mathrm{CO}\right)$ ratios with $25 \% \mathrm{~N}_{2}$, and pellet size on the VTM reduction kinetics were studied using unreacted nuclear shrinkage model. Our study is expected to provide a more valuable technical basis for industrial application of VTM.

\section{Materials and Methods}

\subsection{Preparation of Oxidized VTM Pellets}

The VTM sample used in this study was obtained from the Panzhihua and Xichang areas of Sichuan Province in China. Sample crystal phase of sample was characterized by X-ray powder diffraction (XRD; Bruker D8 ADVANCE, Germany, CuK $\alpha$ radiation, $40 \mathrm{kV}, 40 \mathrm{~mA}$ ). The XRD patterns of the VTM are shown in Figure 1a. As can be seen from Figure 1a, the main mineral phases of the VTM are magnetite $\left(\mathrm{Fe}_{3} \mathrm{O}_{4}\right)$ and Ilmenite $\left(\mathrm{FeTiO}_{3}\right)$. Elements $\mathrm{Ti}$ and $\mathrm{Fe}$ are closely associated to each other in the mineral phase.

The oxidized VTM pellets were prepared as follows. Then the VTM was fully mixed with $1 \mathrm{wt}$ $\%$ binder and $8.5 \mathrm{wt} \%$ water and then pelletized to the diameters of $6-8 \mathrm{~mm}, 8-10 \mathrm{~mm}, 10-12 \mathrm{~mm}$, 12-14 mm, and 14-16 mm in a disc pelletizer (Hong Xing Company, Shaoxing, China). Then, the VTM pellets were loaded into a quartz reactor after being dried at $110^{\circ} \mathrm{C}$ for $4 \mathrm{~h}$. Finally, the VTM pellets were calcined at $1350{ }^{\circ} \mathrm{C}$ for $20 \mathrm{~min}$ under the air conditions. The main chemical compositions are displayed in Table 1, while the XRD patterns of the oxidized VTM pellets are shown in Figure $1 \mathrm{~b}$. It can be seen that the main mineral phases of oxidized VTM pellets were hematite $\left(\mathrm{Fe}_{2} \mathrm{O}_{3}\right)$ and pseudobrookite $\left(\mathrm{Fe}_{2} \mathrm{TiO}_{5}\right)$. It can be concluded that $\mathrm{Fe}_{3} \mathrm{O}_{4}$ and $\mathrm{FeTiO}_{3}$ transformed to hematite $\mathrm{Fe}_{2} \mathrm{O}_{3}$ and $\mathrm{Fe}_{2} \mathrm{TiO}_{5}$ during the pre-oxidation process. 

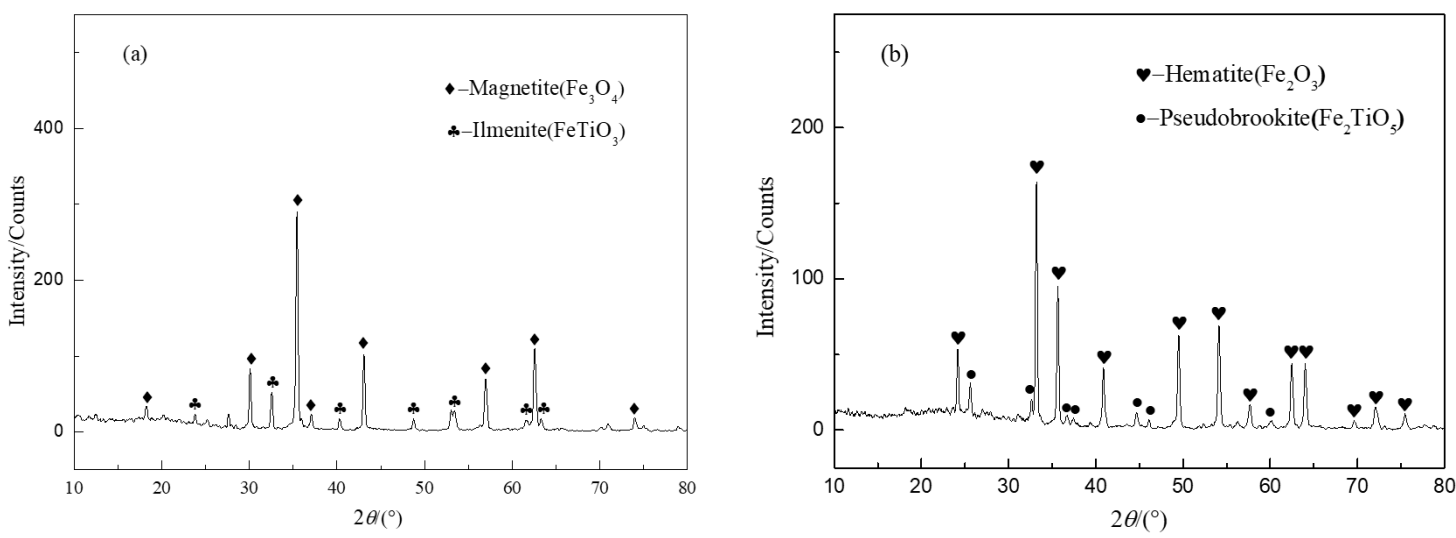

Figure 1. XRD patterns of the sample: (a) the VTM; (b) the oxidized VTM pellets.

Table 1. Main chemical compositions of oxidized VTM pellets (wt \%).

\begin{tabular}{cccccccccc}
\hline $\mathrm{TFe}$ & $\mathrm{FeO}$ & $\mathrm{TiO}_{2}$ & $\mathrm{SiO}_{2}$ & $\mathrm{Al}_{2} \mathrm{O}_{3}$ & $\mathrm{MgO}$ & $\mathrm{CaO}$ & $\mathrm{V}_{2} \mathrm{O}_{5}$ & $\mathrm{MnO}$ & $\mathrm{S}$ \\
\hline 45.50 & 0.59 & 13.40 & 8.42 & 6.54 & 3.28 & 1.40 & 0.54 & 0.32 & 0.037 \\
\hline
\end{tabular}

\subsection{Experimental Measurements}

In this study, $200 \mathrm{~g}$ of heated oxidized VTM pellets directly react with reducing gas in the furnace. The experimental setup is shown in Figure 2. The equipment (Beijing Hengiiu Experimental Equipment Co., Ltd., Beijing, China) consisted of a reducing gas flow control cabinet, a tube furnace, a high temperature resistant reactor made of steel alloy, a coal gas analyzer $(3012 \mathrm{H}$ Automatic Smoke and Gas analyzer" produced in China), an electronic balance and a computer.

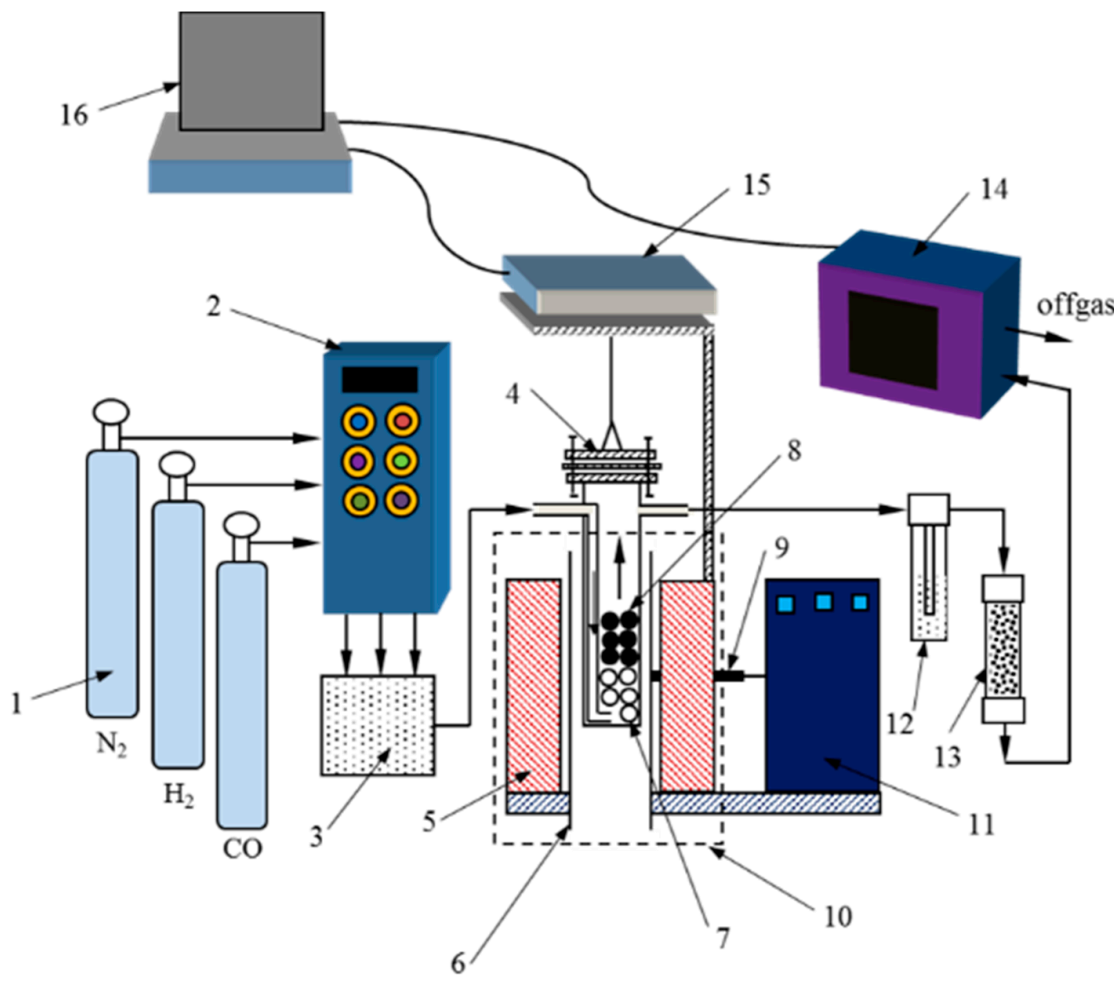

Figure 2. Schematic of the experimental apparatus: 1-gas cylinder, 2-flow control cabinet, 3-gas mixing chamber, 4-reactor, 5-fever zone, 6-alundum tube, 7-corundum ball, 8-oxidized VTM pellets, 9-thermocouple, 10-tube furnace, 11-temperature controlling cabinet, 12-wash bottle, 13-drying bottle, 14-coal gas analyzer, 15-electronic balance, 16-computer. 
Firstly, $400 \mathrm{~g}$ corundum balls with average diameter of $1 \mathrm{~cm}$ were placed at the bottom of the reactor to disperse the reducing gases, and the oxidized VTM pellets were laid evenly above the corundum balls. A gasket made of silica gel was placed between the flanges to improve the air tightness of the reactor. Then the blind flange of the reactor was then closed. The inlet pipe and the exit pipe were connected with the reactor, and the reactor was filled with $\mathrm{N}_{2}$ to check the air tightness. Upon satisfactory air tightness, the reactor was suspended on the bottom of the electronic balance placed above the tube furnace. The tube furnace was turned on, and the temperature program was as the heat was applied. During the entire heating process, the reactor was filled with $\mathrm{N}_{2}$. When the temperature reached a specified level, the electronic balance and the coal gas analyzer were turned on and the data were recorded. The $\mathrm{N}_{2}$ was replaced by the reducing gas to carry out the reduction. Afterward, the reducing gas was switched for $\mathrm{N}_{2}$. Finally, the sample was taken from furnace the after cooling.

$\mathrm{H}_{2}$, $\mathrm{CO}$ and $\mathrm{N}_{2}$ controlled by flow-controlled cabinet were fully mixed in the mixing chamber in the reduction reaction, and the reaction pressure was $1 \mathrm{~atm}$. The gas mixture entered the bottom of the reactor through the inlet pipe along the inner wall of reactor. Afterward, the reducing gas mixture met with the oxidized VTM pellets. The mass change was continuously recorded by the electronic balance and stored in the computer. It was critical to completely remove the dust and vapor in the offgas to avoid damaging the coal-gas analyzer. Thus, the offgas firstly entered into the water-wash bottle followed by a drying bottle. Later, we measured the chemical components of offgas online using the coal-gas analyzer. Finally, the off-gas was emptied. After the samples being reduced for $240 \mathrm{~min}$, the VTM pellets were cooled to room temperature under an $\mathrm{N}_{2}$ atmosphere for later testing.

The reduction degree of oxidized VTM pellets can be calculated as follows [15]:

$$
R=\frac{m\left(\mathrm{O}_{\mathrm{L}}\right)}{m_{0}\left(\mathrm{O}_{\mathrm{L}}\right)}=\left(\frac{0.11 w(\mathrm{FeO})}{0.43 w(\mathrm{TFe})}+\frac{m_{1}-m_{2}}{m_{1} \times 0.43 w(\mathrm{TFe})}\right) \times 100 \%
$$

In which $R$ is reduction degree of iron, $m_{0}\left(\mathrm{O}_{\mathrm{L}}\right)$ is the total weight of $\mathrm{O}$ which bonds with $\mathrm{Fe}$ in oxidized VTM pellets, $m\left(\mathrm{O}_{\mathrm{L}}\right)$ is the weight loss of $\mathrm{O}$ that bonds with Fe during reduction, $w(\mathrm{TFe})$ and $w(\mathrm{FeO})$ are the mass fraction of TFe and $\mathrm{FeO}$ respectively, in oxidized VTM pellets, $m_{1}$ is the mass of the VTM pellet before reduction, and $m_{2}$ is the mass of the VTM pellet in reduction process. The parameters 0.11 and 0.43 represent the oxygen demand conversion coefficients when converting $\mathrm{FeO}$ and $\mathrm{Fe}$ to $\mathrm{Fe}_{2} \mathrm{O}_{3}$, respectively.

\subsection{Reduction Kinetics Analysis}

Based on previous research $[15,16]$, it can be concluded that the reduction of the oxidized VTM pellets proceed topochemically. Therefore, the kinetic model used to describe the iron ore reduction was the un-reacted shrinking core model. This model includes the processes of external diffusion of gaseous species, intrinsic chemical reactions, and the diffusion of gas species. Under the condition of the mixture of $\mathrm{H}_{2}, \mathrm{CO}$ and $\mathrm{N}_{2}$, the total reduction time can be calculated according to the Equation (2), which is based on the un-reacted shrinking core model. Therefore, the rate equations can be obtained as shown in Equations (3) and (4). According to Equations (3) and (4), multiple graphs can be drawn to investigate the actual rate-controlling step of the reduction process. If the process is controlled by the intrinsic chemical reaction, the plot of $1-(1-R)^{\frac{1}{3}}$ vs. time should be a straight line. For the diffusion of gas species controlling step, the plot of $1-\frac{2}{3} R-(1-R)^{\frac{2}{3}}$ vs. time should be a straight line. In Equation (2), Equation (3) and Equation (4), $t$ is the total reduction time ( $\mathrm{min}), k$ is the reduction rate constant $(\mathrm{cm} / \mathrm{min}), r_{0}$ is characteristic initial radius of the pellet $(\mathrm{cm}), \rho_{0}$ is initial oxygen concentration in the pellet $\left(\mathrm{mol} / \mathrm{cm}^{3}\right), k_{0}$ is the parameter constant, $c_{0}$ and $c_{\mathrm{q}}$ are reduction gas concentration at granule surface and in equilibrium respectively $\left(\mathrm{mol} / \mathrm{cm}^{3}\right)$, and $D_{\mathrm{e}}$ is the effective diffusion coefficient $\left(\mathrm{cm}^{2} / \mathrm{min}\right)$. 


$$
\begin{gathered}
t=\frac{r_{0} \rho_{0}}{k_{0}\left(c_{0}-c_{\mathrm{q}}\right)}\left[1-(1-R)^{\frac{1}{3}}\right]+\frac{r_{0}^{2} \rho_{0}}{D_{\mathrm{e}}\left(c_{0}-c_{\mathrm{q}}\right)}\left[1-\frac{2}{3} R-(1-R)^{\frac{2}{3}}\right] \\
k t=1-(1-R)^{\frac{1}{3}} \\
k t=1-\frac{2}{3} R-(1-R)^{\frac{2}{3}}
\end{gathered}
$$

\subsection{Characterization}

Sample crystal phase of sample was characterized by X-ray powder diffraction (XRD; Bruker D8, $\mathrm{CuK} \alpha$ radiation, $40 \mathrm{kV}, 40 \mathrm{~mA}$ ).

\section{Results and Discussion}

\subsection{Reduction Temperature}

The reduction of VTM pellets was carried out in the temperature range of $973 \mathrm{~K}-1373 \mathrm{~K}$ with the intervals of $100 \mathrm{~K}$. Other specific experimental conditions were controlled: The total gas flow was $5 \mathrm{~L} \cdot \mathrm{min}^{-1}$, the proportion of $\mathrm{N}_{2}$ was $25 \%$, the proportion of $\mathrm{H}_{2}$ and $\mathrm{CO}$ was $75 \%$ (the $\mathrm{H}_{2} /\left(\mathrm{H}_{2}+\mathrm{CO}\right)=$ $1 / 2$ ), and the diameter of oxidized VTM pellets was $10-12 \mathrm{~mm}$. The experimental results are shown in Figure 3.

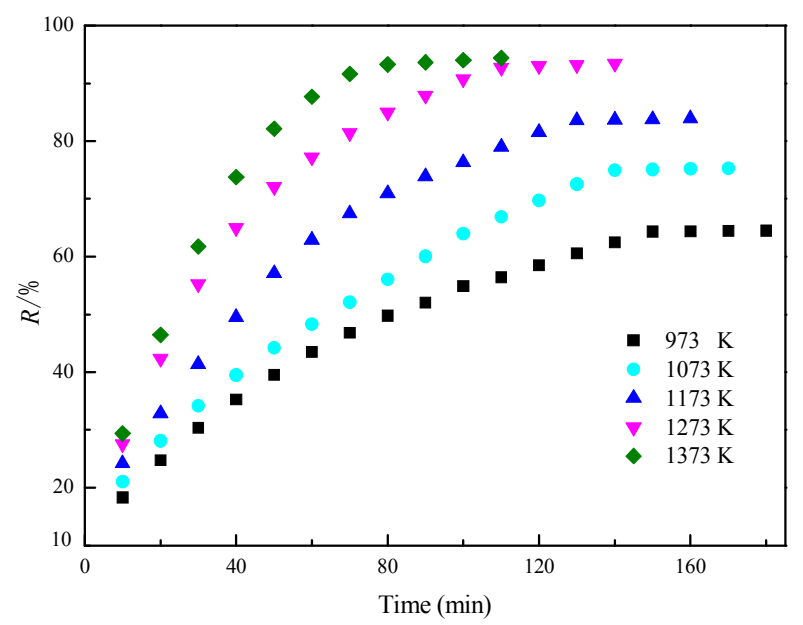

Figure 3. The reduction degree curves of oxidized VTM pellets at $973 \mathrm{~K}-1373 \mathrm{~K}$ in $\mathrm{H}_{2} /\left(\mathrm{H}_{2}+\mathrm{CO}\right)=$ $1 / 2$ atmosphere.

It can be seen that the reduction degree of oxidized VTM pellets gradually increased with the reduction time. The reduction percentages were $49.8 \%, 56.0 \%, 71.0 \%, 85.0 \%$ and $93.3 \%$ at $973 \mathrm{~K}, 1073 \mathrm{~K}$, $1173 \mathrm{~K}, 1273 \mathrm{~K}$ and $1373 \mathrm{~K}$, respectively, for $80 \mathrm{~min}$ in $\mathrm{H}_{2} /\left(\mathrm{H}_{2}+\mathrm{CO}\right)=1 / 2$ atmosphere, indicating that the reaction temperature can also strongly influence the reduction rate of oxidized VTM pellets. The reduction degree can be elevated with the increase of temperature because crystal lattice has a higher energy in higher temperature. In addition, $\mathrm{H}_{2}$ and $\mathrm{CO}$ have higher reduction thermodynamic potential energy as the temperature increases. Thus, the reduction temperature of oxidized VTM pellets is recommended to exceed $1273 \mathrm{~K}$ in actual industrial production.

Figure 4 shows the XRD patterns of the VTM pellets after the reduction process. The results indicate that $\mathrm{Fe}$ can be produced at $973 \mathrm{~K}-1373 \mathrm{~K}$. In addition, the Ti-bearing main mineral phase changes with the increase in temperature. The phase of $\mathrm{Fe}_{2} \mathrm{TiO}_{5}$ disappears, and the phase of the reduction product is $\mathrm{Fe}_{2} \mathrm{TiO}_{4}$ at $973 \mathrm{~K}$. As the temperature increases, $\mathrm{Fe}_{2} \mathrm{TiO}_{4}$ is reduced to $\mathrm{FeTiO}_{3}$. 
With the temperature further increasing to $1173 \mathrm{~K}, \mathrm{FeTiO}_{3}$ is reduced to $\mathrm{FeTi}_{2} \mathrm{O}_{5}$. Therefore, the most probable reaction mechanism of the reduction process can be described in Equations (5)-(16).

$$
\begin{gathered}
3 \mathrm{Fe}_{2} \mathrm{O}_{3}+\mathrm{H}_{2}(\mathrm{~g})=2 \mathrm{Fe}_{3} \mathrm{O}_{4}+\mathrm{H}_{2} \mathrm{O}(\mathrm{g}) \\
\mathrm{Fe}_{3} \mathrm{O}_{4}+\mathrm{H}_{2}(\mathrm{~g})=3 \mathrm{FeO}+\mathrm{H}_{2} \mathrm{O}(\mathrm{g}) \\
\mathrm{FeO}+\mathrm{H}_{2}(\mathrm{~g})=\mathrm{Fe}+\mathrm{H}_{2} \mathrm{O}(\mathrm{g}) \\
3 \mathrm{Fe}_{2} \mathrm{O}_{3}+\mathrm{CO}(\mathrm{g})=2 \mathrm{Fe}_{3} \mathrm{O}_{4}+\mathrm{CO}_{2}(\mathrm{~g}) \\
\mathrm{Fe}_{3} \mathrm{O}_{4}+\mathrm{CO}(\mathrm{g})=3 \mathrm{FeO}+\mathrm{CO}_{2}(\mathrm{~g}) \\
\mathrm{FeO}+\mathrm{CO}(\mathrm{g})=\mathrm{Fe}+\mathrm{CO}_{2}(\mathrm{~g}) \\
\mathrm{Fe}_{2} \mathrm{TiO}_{5}+\mathrm{H}_{2}(\mathrm{~g})=\mathrm{Fe}_{2} \mathrm{TiO}_{4}+\mathrm{H}_{2} \mathrm{O}(\mathrm{g}) \\
\mathrm{Fe}_{2} \mathrm{TiO}_{5}+\mathrm{CO}(\mathrm{g})=\mathrm{Fe}_{2} \mathrm{TiO}_{4}+\mathrm{CO}_{2}(\mathrm{~g}) \\
\mathrm{Fe}_{2} \mathrm{TiO}_{4}+\mathrm{H} 2(\mathrm{~g})=\mathrm{Fe}+\mathrm{FeTiO}_{3}+\mathrm{H}_{2} \mathrm{O}(\mathrm{g}) \\
\mathrm{Fe}_{2} \mathrm{TiO}_{4}+\mathrm{CO}(\mathrm{g})=\mathrm{Fe}+\mathrm{FeTiO}_{3}+\mathrm{CO}_{2}(\mathrm{~g}) \\
2 \mathrm{FeTiO}_{3}+\mathrm{H}(\mathrm{g})=\mathrm{Fe}+\mathrm{FeTi}_{2} \mathrm{O}_{5}+\mathrm{H}_{2} \mathrm{O}(\mathrm{g}) \\
2 \mathrm{FeTiO}_{3}+\mathrm{CO}(\mathrm{g})=\mathrm{Fe}+\mathrm{FeTi}_{2} \mathrm{O}_{5}+\mathrm{CO}_{2}(\mathrm{~g})
\end{gathered}
$$

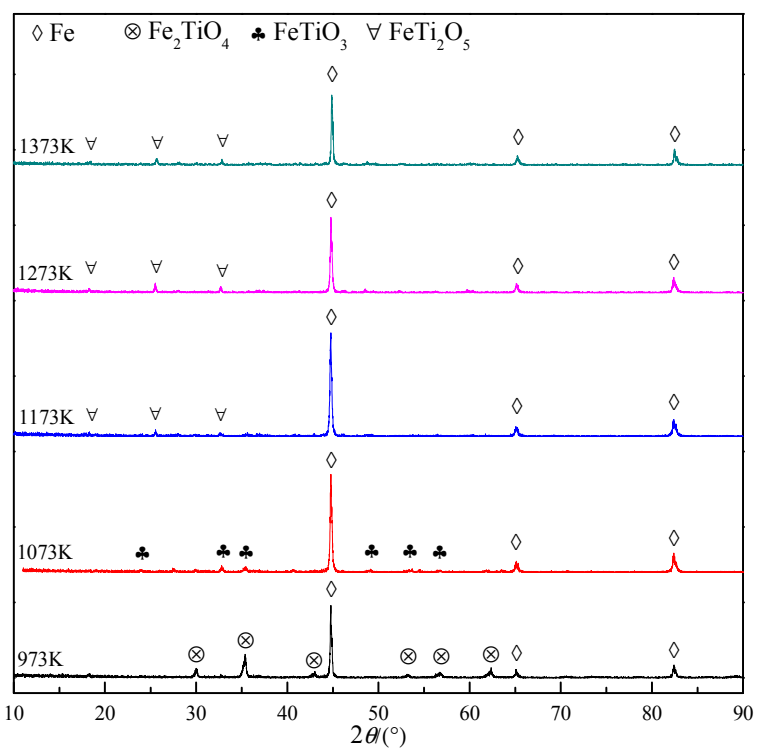

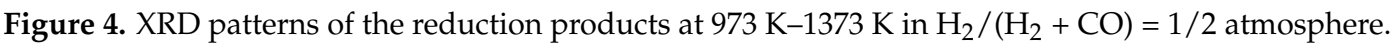

On the basis of Equations (3) and (4), kinetic results of the VTM pellets are shown in Figure 5a,b. The figure clearly shows that there are two stages in the whole reduction process: an early stage and a later stage. The correlation coefficients $\left(R^{2}\right)$ of the straight lines are $0.982,0.998,0.983,0.985$ and 0.986 at the early stage. The correlation coefficient $\left(R^{2}\right)$ of the straight lines are $0.999,0.998,0.985,0.993$ and 0.997 at the later stage. Thus, the strong linear relationships indicate that the reduction processes of the early stage and the later stage are controlled by interface chemical reaction and diffusion, respectively. The values of the reduction rate constant of two stages are presented in Table 2 . The reduction rate constants of both the early stage and the later stage increase with increasing temperature. This indicates that an increase in temperature can effectively improve the reduction process. 

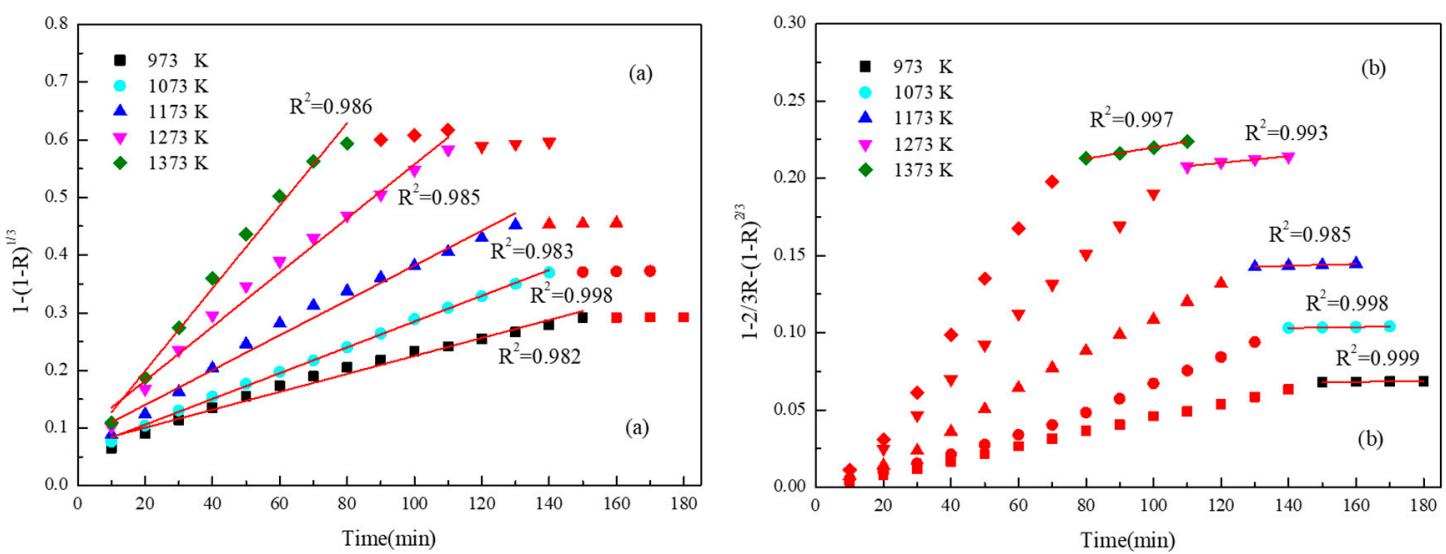

Figure 5. Plot of $1-(1-R)^{\frac{1}{3}}$ vs. time (a) and plot of $1-\frac{2}{3} R-(1-R)^{\frac{2}{3}}$ vs. time (b) at $973 \mathrm{~K}-1373 \mathrm{~K}$ in $\mathrm{H}_{2} /\left(\mathrm{H}_{2}+\mathrm{CO}\right)=1 / 2$ atmosphere.

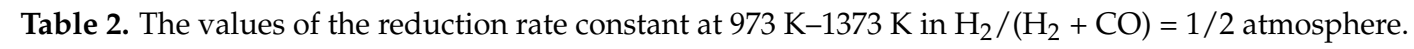

\begin{tabular}{cccccc}
\hline Temperature & $\mathbf{9 7 3} \mathbf{~ K}$ & $\mathbf{1 0 7 3 ~ K}$ & $\mathbf{1 1 7 3 ~ K}$ & $\mathbf{1 2 7 3 ~ K}$ & $\mathbf{1 3 7 3 ~ K}$ \\
\hline Intrinsic Chemical Reaction Control & 0.00156 & 0.00224 & 0.00302 & 0.00469 & 0.00717 \\
Diffusion Control & $1.34 \times 10^{-5}$ & $3.88 \times 10^{-5}$ & $6.15 \times 10^{-5}$ & $2.13 \times 10^{-4}$ & $3.70 \times 10^{-4}$ \\
\hline
\end{tabular}

According to the Arrhenius equation, the relationship between the reaction temperature $(T)$ and the reduction rate constant $(k)$ can be obtained as shown in Equation (17). In Equation (17), $E$ is the activation energy $\left(\mathrm{kJ} \cdot \mathrm{mol}^{-1}\right), k_{0}$ is the frequency factor.

$$
k=k_{0} \exp \left(-\frac{E}{R T}\right)
$$

Taking the natural logarithm of both sides in Equation (17):

$$
\ln k=-\frac{E}{R T}+\ln k_{0}
$$

The plot of lnk vs. $1 / T$ in $\mathrm{H}_{2} /\left(\mathrm{H}_{2}+\mathrm{CO}\right)=1 / 2$ atmosphere is shown in Figure $6 \mathrm{a}, \mathrm{b}$. The activation energies of intrinsic chemical reaction control stage and diffusion control stage can be evaluated based on the data of Figure 6 and Equation (18), and the calculated values are $41.65 \mathrm{~kJ} / \mathrm{mol}$ and $92.45 \mathrm{~kJ} / \mathrm{mol}$, respectively. Therefore, the value of activation energy in intrinsic chemical reaction control stage is lower than that in diffusion control stage for gas-based reduction of oxidized VTM pellets.
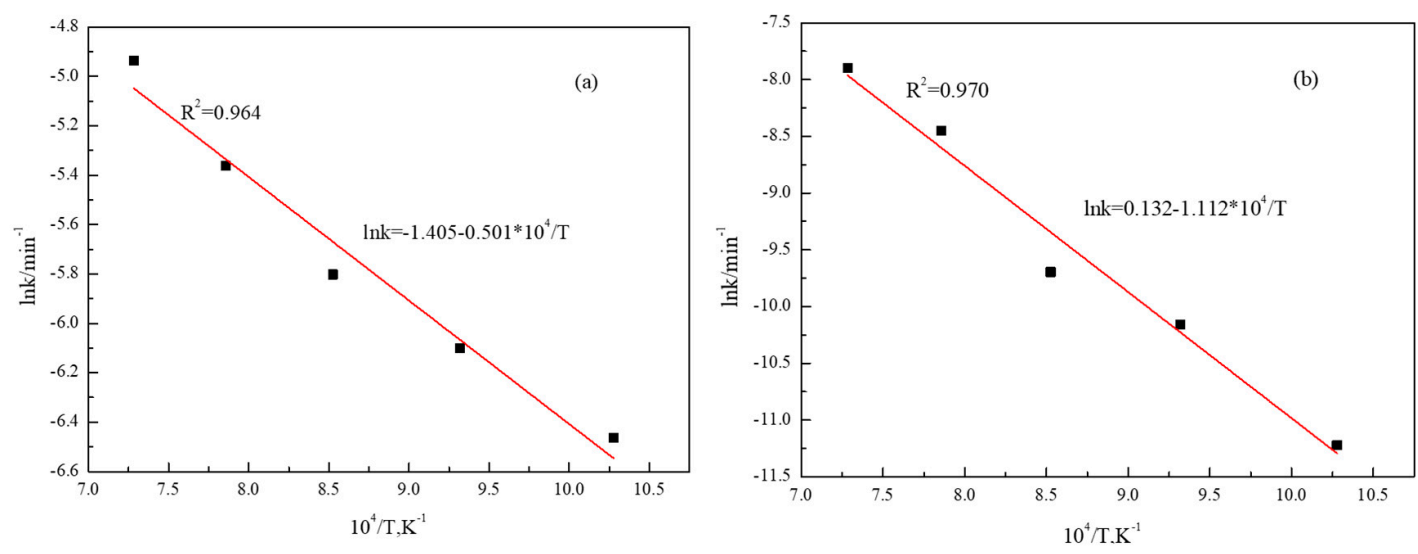

Figure 6. The Arrhenius plot of reaction degree constant $k$ vs. temperature (a) intrinsic chemical

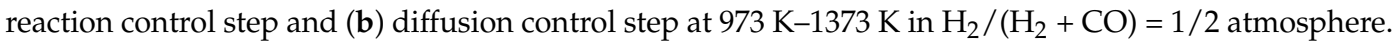




\subsection{Gas Composition}

To investigate the effect of gas composition on the reduction of oxidized VTM pellets, the experiment was carried out under the $\mathrm{H}_{2} /\left(\mathrm{H}_{2}+\mathrm{CO}\right)$ ratios of $0,1 / 4,1 / 3,1 / 2,2 / 3,3 / 4$, and 1 . Other specific experimental conditions were controlled as follows: The reduction temperature was $1273 \mathrm{~K}$, the total gas flow was $3 \mathrm{~L} \cdot \mathrm{min}^{-1}$, the proportion of $\mathrm{N}_{2}$ was $25 \%$, the proportion of $\mathrm{H}_{2}$ and $\mathrm{CO}$ was $75 \%$, the oxidized VTM pellets diameter was 10-12 $\mathrm{mm}$. The experimental results are shown in Figure 7. For reducing under the condition of $\mathrm{H}_{2} /\left(\mathrm{H}_{2}+\mathrm{CO}\right)=0$ for $150 \mathrm{~min}$, the reduction degree of VTM pellets was only $72.6 \%$. As the ratio of $\mathrm{H}_{2} /\left(\mathrm{H}_{2}+\mathrm{CO}\right)$ increased to 1 , the reduction degree of VTM pellets increases to $92.1 \%$. This shows that the reduction degree of VTM pellets increases with the increasing $\mathrm{H}_{2} /\left(\mathrm{H}_{2}+\mathrm{CO}\right)$ ratio. Previous research has confirmed that $\mathrm{H}_{2}$ has higher reduction capacity and utilization than $\mathrm{CO}$ at high temperature $(T>1084 \mathrm{~K})[27,28]$.

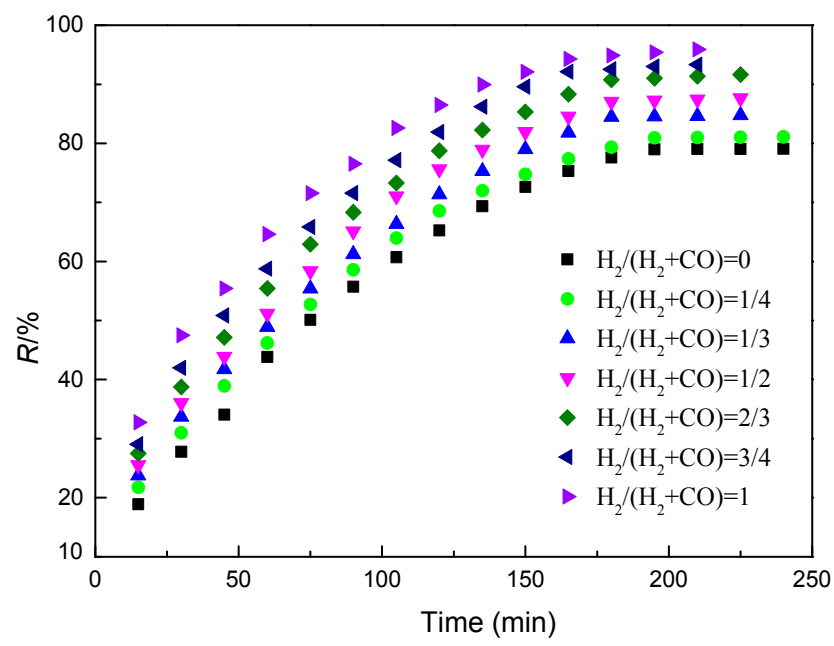

Figure 7. The reduction degree curves of oxidized VTM pellets at $1273 \mathrm{~K}$ with $\mathrm{H}_{2} /\left(\mathrm{H}_{2}+\mathrm{CO}\right)$ ratios.

Figure 8 presents the XDR patterns of the reduction VTM pellets products that were obtained after being reduced by the reduction gas with different $\mathrm{H}_{2} /\left(\mathrm{H}_{2}+\mathrm{CO}\right)$ ratios at $1273 \mathrm{~K}$ for $240 \mathrm{~min}$. The pattern indicates that when the proportion of $\mathrm{H}_{2} /\left(\mathrm{H}_{2}+\mathrm{CO}\right)$ is small, the phase of $\mathrm{Fe}_{2} \mathrm{TiO}_{5}$ disappears, and the main phase of the reduction product is $\mathrm{FeTiO}_{3}$. The most probable reaction mechanism is given by Equations (11-14). As the ratio of $\mathrm{H}_{2} /\left(\mathrm{H}_{2}+\mathrm{CO}\right)$ increases to $2, \mathrm{FeTiO}_{3}$ is reduced to $\mathrm{FeTi}_{2} \mathrm{O}_{5}$. The most probable reactions are Equation (15), and Equation (16).

Figure $9 \mathrm{a}, \mathrm{b}$ show the plot of $1-(1-R)^{\frac{1}{3}}$ vs. time and plot of $1-\frac{2}{3} R-(1-R)^{\frac{2}{3}}$ vs. time, respectively, at $1273 \mathrm{~K}$ in different $\mathrm{H}_{2} /\left(\mathrm{H}_{2}+\mathrm{CO}\right)$ ratios. There are also both the early stage and the later stage, these are controlled by interface chemical reaction and by diffusion, respectively. The plots show that the diffusion-control step was significantly shortened as the ratio of $\mathrm{H}_{2} /\left(\mathrm{CO}+\mathrm{H}_{2}\right)$ increased. Therefore, the kinetic conditions of reduction can be improved at $1273 \mathrm{~K}$ by increasing the $\mathrm{H}_{2} /\left(\mathrm{H}_{2}+\right.$ $\mathrm{CO})$ ratio. The hydrogen-rich reduction gas is definitely beneficial to the reduction of oxidized VTM pellets in the actual industrial production. 


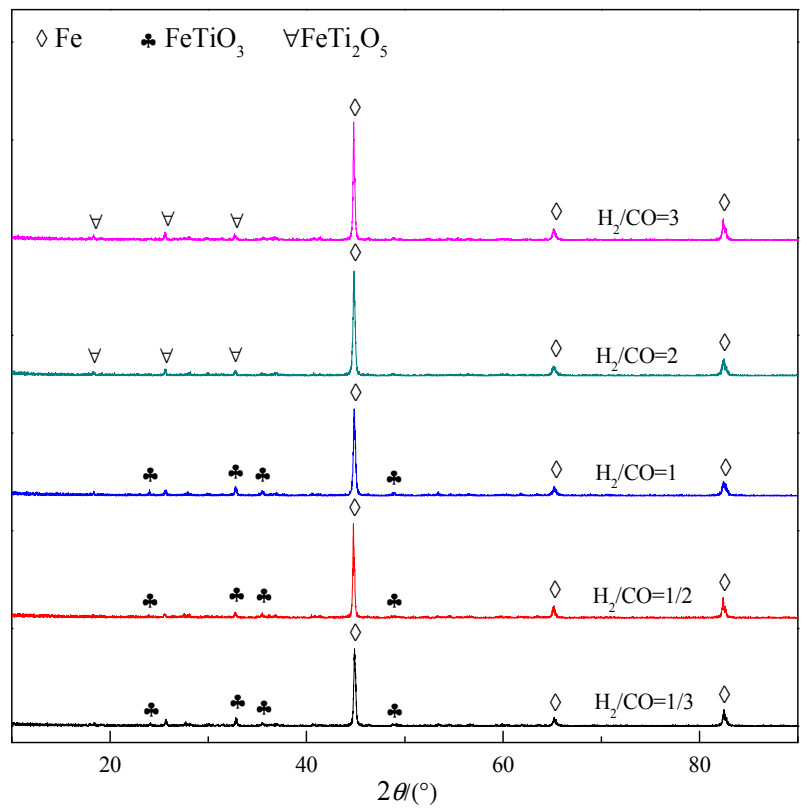

Figure 8. XRD patterns of reduction products at $1273 \mathrm{~K}$ with $\mathrm{H}_{2} /\left(\mathrm{H}_{2}+\mathrm{CO}\right)$ ratios.
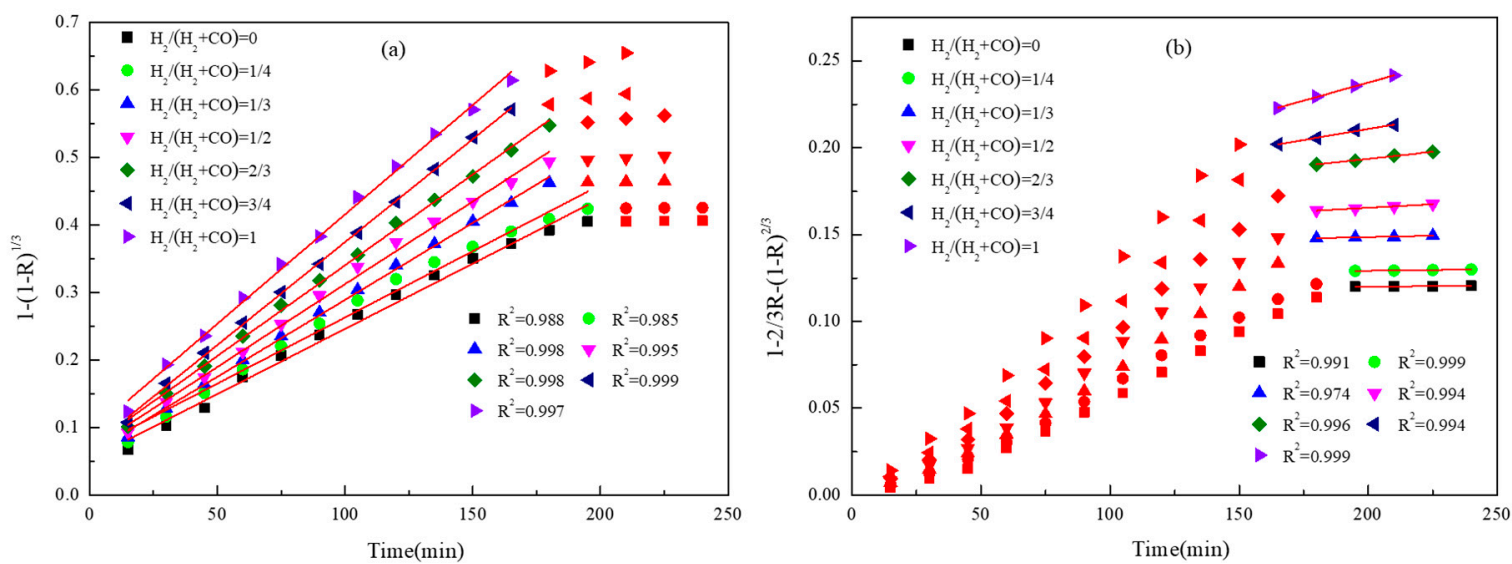

Figure 9. The reduction degree curves of oxidized VTM pellets at $1273 \mathrm{~K}$ with $\mathrm{H}_{2} /\left(\mathrm{H}_{2}+\mathrm{CO}\right)$ ratios. (a) the plot of $1-(1-R)^{\frac{1}{3}}$ vs. time and (b) plot of $1-\frac{2}{3} R-(1-R)^{\frac{2}{3}}$ vs. time.

\subsection{Pellet Size}

To investigate the effect of pellet size on the reduction of oxidized VTM pellets, the reduction experiments were carried out with the oxidized VTM pellets having diameters of 6-8 $\mathrm{mm}, 8-10 \mathrm{~mm}$, 10-12 mm, 12-14 mm, and 14-16 mm. Other specific experimental conditions were as follows: The reduction temperature was $1273 \mathrm{~K}$, the total gas flow was $5 \mathrm{~L} \cdot \mathrm{min}^{-1}$, the proportion of $\mathrm{N}_{2}$ was $25 \%$, the proportion of $\mathrm{H}_{2}$ and $\mathrm{CO}$ was $75 \%$ (the $\mathrm{H}_{2} /\left(\mathrm{H}_{2}+\mathrm{CO}\right)=1 / 2$ ).

As the pellet size changed from $6-8 \mathrm{~mm}$ to $14-16 \mathrm{~mm}$, the resulting reduction degree of the oxidized VTM pellets is shown in Figure 10. It can be seen that the pellet size of oxidized VTM pellets has a strong influence on the reduction degree. The reduction degree increased with the decreasing pellet size. 


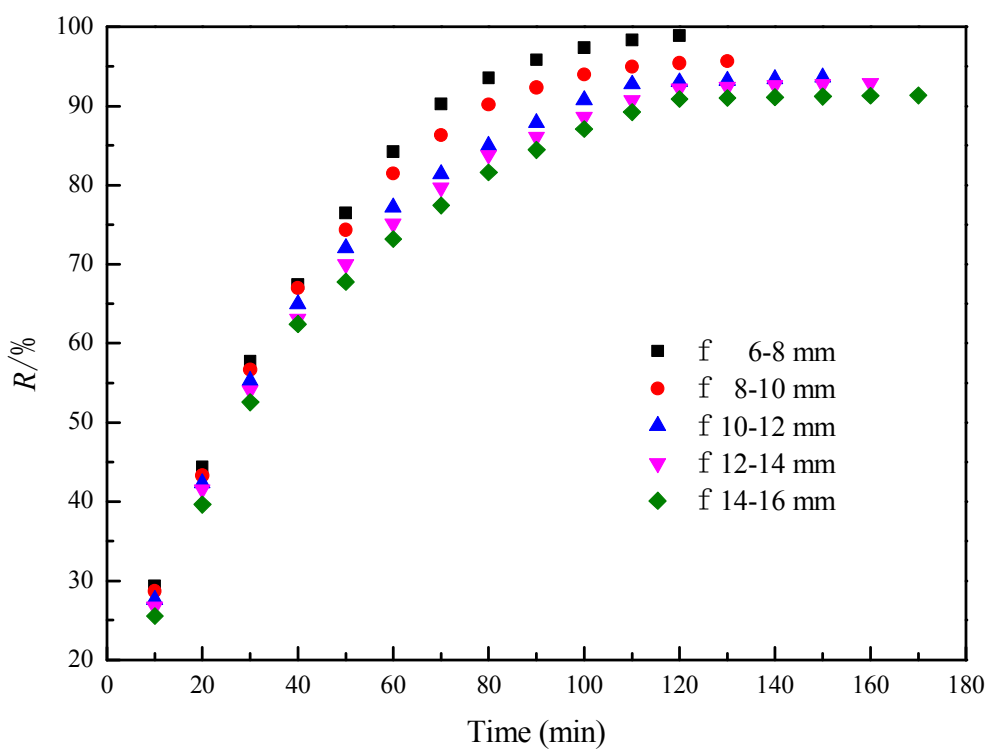

Figure 10. The reduction degree curves of oxidized VTM pellets at $1273 \mathrm{~K}$ with different oxidized VTM pellets diameter in $\mathrm{H}_{2} /\left(\mathrm{H}_{2}+\mathrm{CO}\right)=1 / 2$ atmosphere.

Figure 11 shows the XRD patterns of the reduction VTM pellets products that were obtained at $1273 \mathrm{~K}$ for $240 \mathrm{~min}$ in $\mathrm{H}_{2} /\left(\mathrm{H}_{2}+\mathrm{CO}\right)=1 / 2$ atmosphere. It can be seen that the phase of $\mathrm{FeTiO}_{3}$ can be transferred into that of $\mathrm{Fe}_{2} \mathrm{TiO}_{5}$ with the decrease in pellet diameter. The most probable reaction mechanism is described in Equations (11-14). Until the pellet size decreases to $10-12 \mathrm{~mm}, \mathrm{FeTiO}_{3}$ is reduced to $\mathrm{FeTi}_{2} \mathrm{O}_{5}$. The most probable reactions are Equation (15), and Equation (16). With the continuous decrease of pellet size, the diffractive peaks of $\mathrm{FeTi}_{2} \mathrm{O}_{5}$ become weaker and the peak metallic iron getting stronger, resulting in the enhancement of reduction degree.

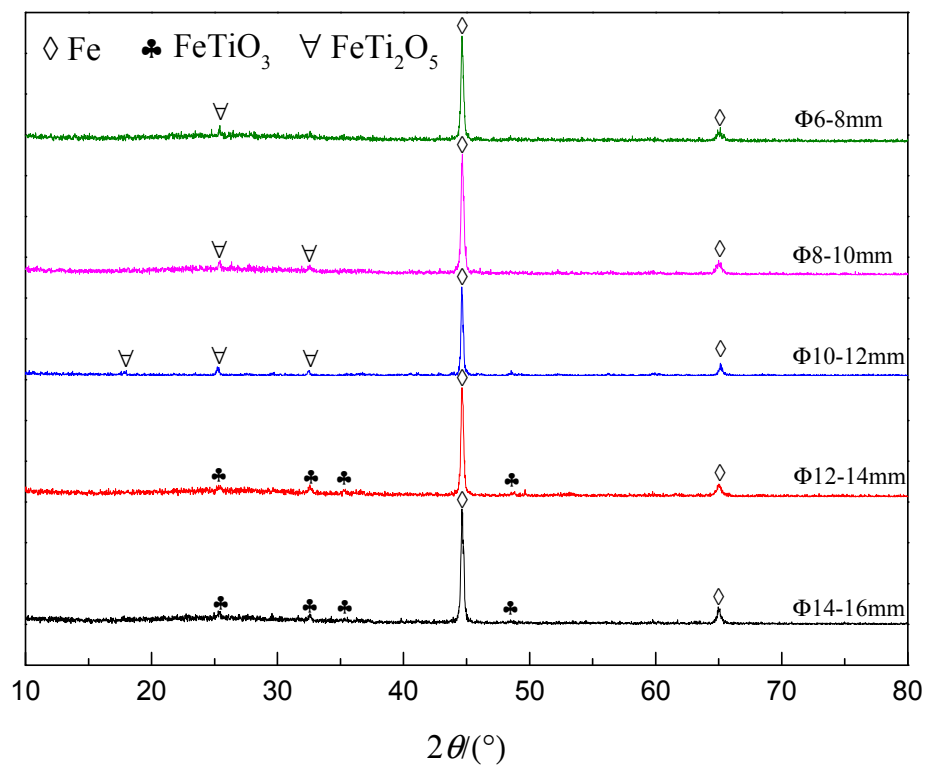

Figure 11. The reduction degree curves of oxidized VTM pellets at $1273 \mathrm{~K}$ with different oxidized VTM pellets diameter in $\mathrm{H}_{2} /\left(\mathrm{H}_{2}+\mathrm{CO}\right)=1 / 2$ atmosphere.

Figure 12a,b show the Plots of $1-(1-R)^{\frac{1}{3}}$ and $1-\frac{2}{3} R-(1-R)^{\frac{2}{3}}$ vs. time with different diameters of oxidized VTM pellets. It is obvious that early stage and the later stage also exists during the reduction process, these are controlled by interface chemical reaction and diffusion, respectively. It is can be seen that the pellet size has strong influence on the later stage. The thickness of the product 
can be decreased with decreasing pellet size during the reduction process. The diffusion degree of gas decreased quickly with the increasing thickness of product layer. This result shows that the diffusion-control step can be shortened via decreasing of the pellet size. Therefore, it is important to select the appropriate pellet size in order to optimize the reduction process. From Figure 12, the values of reaction rate constant can be obtained, and these are listed in Table 3 . The results indicate that the kinetic conditions of reduction can be improved at $1273 \mathrm{~K}$ in $\mathrm{H}_{2} /\left(\mathrm{H}_{2}+\mathrm{CO}\right)=1 / 2$ atmosphere via a decrease in the pellet size.
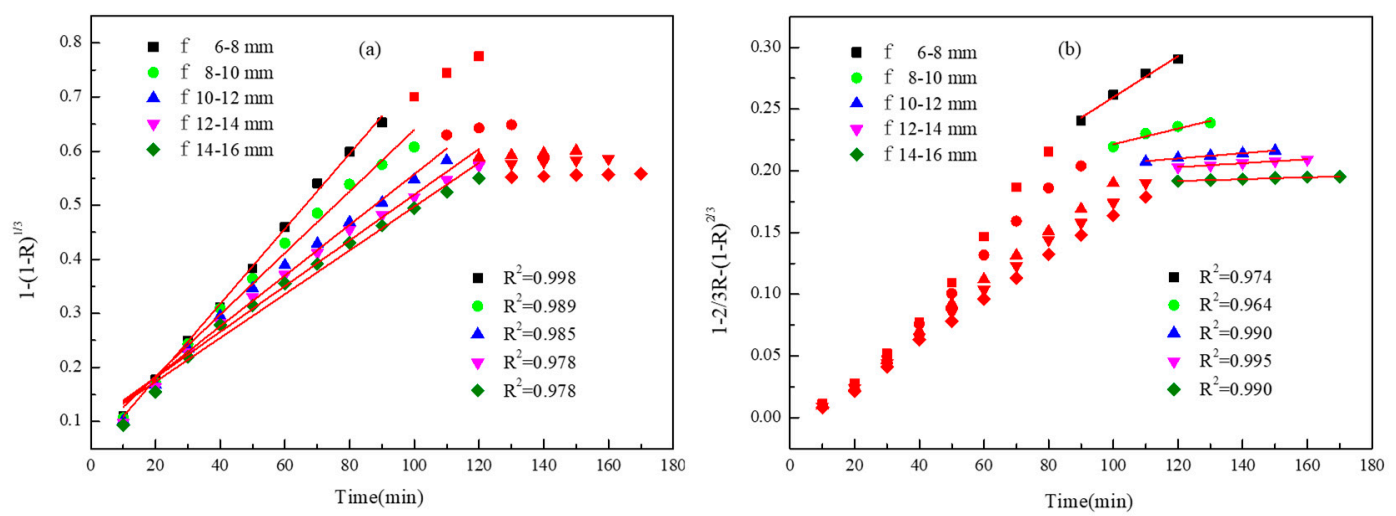

Figure 12. Plot of $1-(1-R)^{\frac{1}{3}}$ vs. time (a) and plot of $1-\frac{2}{3} R-(1-R)^{\frac{2}{3}}$ vs. time (b) at $1273 \mathrm{~K}$ with different oxidized VTM pellets diameter in $\mathrm{H}_{2} /\left(\mathrm{H}_{2}+\mathrm{CO}\right)=1 / 2$ atmosphere.

Table 3. The values of the reduction rate constant at $1273 \mathrm{~K}$ with different oxidized VTM pellets diameter.

\begin{tabular}{cccccc}
\hline Pellets Diameter & $\mathbf{6 - 8} \mathbf{~ m m}$ & $\mathbf{8 - 1 0 ~} \mathbf{~ m}$ & $\mathbf{1 0 - 1 2 ~} \mathbf{~ m}$ & $\mathbf{1 2 - 1 4} \mathbf{~ m m}$ & $\mathbf{1 4 - 1 6} \mathbf{~ m m}$ \\
\hline Intrinsic Chemical Reaction Control & 0.00694 & 0.0057 & 0.00469 & 0.00423 & 0.00405 \\
Diffusion Control & $1.66 \times 10^{-3}$ & $6.35 \times 10^{-4}$ & $2.12 \times 10^{-4}$ & $1.58 \times 10^{-4}$ & $7.64 \times 10^{-5}$ \\
\hline
\end{tabular}

\section{Conclusions}

Gas-based reduction of oxidized VTM pellets in the mixture of $\mathrm{H}_{2}, \mathrm{CO}$, and $\mathrm{N}_{2}$ was systematically investigated at $973 \mathrm{~K}-1373 \mathrm{~K}$. The reduction degree increased with increasing reduction time, reduction temperature, and $\mathrm{H}_{2} /\left(\mathrm{H}_{2}+\mathrm{CO}\right)$ ratios, and decreasing pellet size. The Ti-bearing main mineral phase transformation of oxidized VTM pellets in $\mathrm{H}_{2} /\left(\mathrm{H}_{2}+\mathrm{CO}\right)=1 / 2$ atmosphere is described as $\mathrm{Fe}_{2} \mathrm{TiO}_{5} \rightarrow$ $\mathrm{Fe}_{2} \mathrm{TiO}_{4} \rightarrow \mathrm{FeTiO}_{3} \rightarrow \mathrm{FeTi}_{2} \mathrm{O}_{5}$. The Ti-bearing main mineral phase transformation of the reduction VTM pellets products at $1273 \mathrm{~K}$ is described as $\mathrm{Fe}_{2} \mathrm{TiO}_{5} \rightarrow \mathrm{FeTiO}_{3} \rightarrow \mathrm{FeTi}_{2} \mathrm{O}_{5}$ with the increase of $\mathrm{H}_{2} /\left(\mathrm{H}_{2}+\mathrm{CO}\right)$ ratios and the decrease of pellet size. The most probable reaction mechanism is provided based on the reduction process. The kinetics of oxidized VTM pellet in the reduction process is successfully modeled as a shrinking unreacted-core. For the entire reduction process, the kinetics study indicated that there are an early stage and a later stage that are controlled by interface chemical reaction and diffusion, respectively. In addition, the diffusion-control step can be observably shortened via decreasing the pellet size because the thickness of the product layer becomes thinner in the reduction process.

Author Contributions: Conceptualization, X.W.; data curation, L.M.; formal analysis, J.C.; funding acquisition, X.W.; investigation, J.C. and W.C.; methodology, J.C. and Y.J.; resources, X.W.; software, X.W.; supervision, X.W.; visualization, J.C.; writing—original draft, J.C.; writing—review \& editing, W.C.

Funding: This work was supported by the ministry of land and resources public welfare industry research project (201511062-02).

Conflicts of Interest: The authors declare no conflict of interest. 


\section{References}

1. Alfantazi, A.M.; Moskalyk, R.R. Processing of indium: A review. Miner. Eng. 2003, 16, 687-694. [CrossRef]

2. Zhou, L.H.; Zeng, F.H. Reduction mechanisms of vanadium-titanomagnetite-non-coking coal mixed pellet. Ironmak. Steelmak. 2014, 38, 59-64. [CrossRef]

3. Zhang, J.L.; Xing, X.D.; Cao, M.M.; Jiao, K.X.; Wang, C.L.; Ren, S. Reduction kinetics of vanadium titano-magnetite carbon composite pellets adding catalysts under high temperature. J. Iron. Steel Res. Int. 2013, 20, 1-7. [CrossRef]

4. Guo, L.; Yu, J.T.; Tang, J.K.; Lin, Y.H.; Guo, Z.C.; Tang, H.Q. Influence of coating MgO on sticking and functional mechanism during fluidized bed reduction of vanadium titano-magnetite. J. Iron. Steel Res. Int. 2015, 22, 464-472. [CrossRef]

5. Bai, Y.Q.; Cheng, S.S.; Bai, Y.M. Analysis of Vanadium-bearing titanomagnetite sintering process by dissection of sintering bed. J. Iron Steel Res. Int. 2011, 18, 8-15. [CrossRef]

6. Lv, X.; Lun, Z.; Yin, J.; Bai, C. Carbothermic reduction of vanadium titanomagnetite by microwave irradiation and smelting behavior. ISIJ Int. 2013, 53, 1115-1119. [CrossRef]

7. Zheng, F.; Chen, F.; Guo, Y.; Jiang, T.; Travyanov, A.Y.; Qiu, G. Kinetics of hydrochloric acid leaching of titanium from titanium-bearing electric furnace slag. JOM 2016, 68, 1-9. [CrossRef]

8. Sui, Y.L.; Guo, Y.F.; Jiang, T.; Qiu, G.Z. Sticking behaviour of vanadium titano-magnetite oxidised pellets during gas-based reduction and its prevention. Ironmak. Steelmak. 2016, 44, 185-192. [CrossRef]

9. Chen, D.S.; Song, B.; Wang, L.N.; Qi, T.; Wang, Y.; Wang, W.J. Solid state reduction of panzhihua titanomagnetite concentrates with pulverized coal. Miner. Eng. 2011, 24, 864-869. [CrossRef]

10. Guo, Y.F.; Gao, Y.; Tao, J.; Qiu, G.Z. Solid-state reduction behavior of panzhihua ilmenite. J. Cent. South Univ. 2010, 41, 1639-1644.

11. Cao, M.M.; Zhang, J.L.; Xing, X.D.; Wang, C.L.; Bai, Y.N.; Wen, Y.C. Reduction mechanism of vanadium titano-magnetite carbon composite pellets. Iron Steel 2012, 47, 5-12. [CrossRef]

12. Chen, D.S.; Zhao, H.; Hu, G.P.; Qi, T.; Yu, H.D.; Zhang, F.Z.; Wang, L.N.; Wang, W.J. An extraction process to recover vanadium from low-grade vanadium-bearing titanomagnetite. J. Hazard. Mater. 2015, 294, 35-40. [CrossRef]

13. Tang, J.; Chu, M.S.; Ying, Z.W.; Li, F.; Feng, C.; Liu, Z.G. Non-isothermal gas-based direct reduction behavior of high chromium vanadium-titanium magnetite pellets and the melting separation of metallized pellets. Metals 2017, 7, 153. [CrossRef]

14. Tripathi, D.; Mani, V.; Pal, R.P. Vanadium in biosphere and its role in biological processes. Biol. Trace Elem. Res. 2018, 186, 52-67. [CrossRef] [PubMed]

15. Sui, Y.L.; Guo, Y.F.; Jiang, T.; Qiu, G.Z. Reduction kinetics of oxidized vanadium titano-magnetite pellets using carbon monoxide and hydrogen. J. Alloy. Compd. 2017, 706, 546-553. [CrossRef]

16. Sui, Y.L.; Guo, Y.F.; Jiang, T.; Xie, X.L.; Wang, S.; Zheng, F.Q. Gas-based reduction of vanadium titano-magnetite concentrate: Behavior and mechanisms. Int. J. Miner. Metall. Mater. 2017, 24, 10-17. [CrossRef]

17. Zhu, Z.; Zhang, W.; Cheng, C.Y. A synergistic solvent extraction system for separating copper from iron in high chloride concentration solutions. Hydrometallurgy 2012, 113-114, 155-159. [CrossRef]

18. Liu, S.S.; Guo, Y.F.; Qiu, G.Z.; Jiang, T.; Chen, F. Preparation of Ti-rich material from titanium slag by activation roasting followed by acid leaching. Trans. Nonferrous Met. Soc. China 2013, 23, 1174-1178. [CrossRef]

19. Tang, J.; Chu, M.S.; Feng, C.; Tang, Y.T.; Liu, Z.G. Melting separation behavior and mechanism of high-chromium vanadium-bearing titanomagnetite metallized pellet got from gas-based direct reduction. ISIJ Int. 2016, 56, 210-219. [CrossRef]

20. Mehdizadeh, A.M.; Klausner, J.F.; Barde, A.; Mei, R. Enhancement of thermochemical hydrogen production using an iron-silica magnetically stabilized porous structure. Int. J. Hydrogen Energy 2012, 37, 8954-8963. [CrossRef]

21. Piotrowski, K.; Mondal, K.; Lorethova, H.; Stonawski, L.; Szymański, T.; Wiltowski, T. Effect of gas composition on the kinetics of iron oxide reduction in a hydrogen production process. Int. J. Hydrogen Energy 2005, 30, 1543-1554. [CrossRef] 
22. Zhao, W.; Chu, M.; Wang, H.; Liu, Z.; Tang, J.; Ying, Z. Volumetric shrinkage characteristics and kinetics analysis of vanadium titanomagnetite carbon composite hot briquette during isothermal reduction. ISIJ Int. 2018, 58, 823-832. [CrossRef]

23. Guo, D.; Hu, M.; Pu, C.; Xiao, B.; Hu, Z.; Liu, S. Kinetics and mechanisms of direct reduction of iron ore-biomass composite pellets with hydrogen gas. Int. J. Hydrogen Energy 2015, 40, 4733-4740. [CrossRef]

24. Huitu, K.; Helle, M.; Helle, H.; Kekkonen, M.; Saxén, H. Optimization of midrex direct reduced iron use in ore-based steelmaking. Steel Res. Int. 2015, 86, 456-465. [CrossRef]

25. Kromhout, J.A.; Ludlow, V.; Mckay, S.; Normanton, A.S.; Thalhammer, M.; Ors, F.; Cimarelli, T. Physical properties of mould powders for slab casting. Ironmak. Steelmak. 2002, 29, 191-193. [CrossRef]

26. Li, W.; Fu, G.Q.; Chu, M.S.; Zhu, M.Y. Oxidation induration process and kinetics of hongge vanadium titanium-bearing magnetite pellets. Ironmak. Steelmak. 2016, 44, 294-303. [CrossRef]

27. Sun, H.Y.; Dong, X.J.; She, X.F.; Xue, Q.G.; Wang, J.S. Reduction mechanism of titanomagnetite concentrate by carbon monoxide. J. Min. Metall. 2013, 49, 263-270. [CrossRef]

28. Huang, Z.C.; Ling-Yun, Y.I.; Hu, P.; Jiang, T. Effects of roast temperature on properties of oxide pellets and its gas-based direct reduction. J. Cent. South Univ. 2012, 43, 2889-2895.

(C) 2019 by the authors. Licensee MDPI, Basel, Switzerland. This article is an open access article distributed under the terms and conditions of the Creative Commons Attribution (CC BY) license (http:/ / creativecommons.org/licenses/by/4.0/). 